\title{
Laparoscopic splenectomy: clip ligation or en-bloc stapling?
}

\author{
Ahmet Türkoğlu(iD), Abdullah Oğuz(iD), Gizem Yaman(iD), Mesut Gül(iD), Burak Veli Ülger(iD) \\ Department of General Surgery, Dicle University School of Medicine, Diyarbakır, Turkey
}

\begin{abstract}
Objective: Various techniques are used in the management of splenic hilum during laparoscopic splenectomy. Among them, the most used ones are polymer clips, en-bloc stapling and ultrasonic devices. To the best of our knowledge, there is no study in the literature comparing the results of clip and stapler techniques. This study was aimed to compare our results of clip ligation and en-bloc stapling of the splenic hilum.
\end{abstract}

Material and Methods: The records of 67 patients undergoing laparoscopic splenectomy between December 2012 and October 2017 were reviewed. Patients were divided into two groups according to surgical method (stapler group: 26 patients and clip group: 41 patients). Patient age, sex, diagnosis, surgical technique, operation time, spleen dimensions, perioperative complications, postoperative hospital stay, blood transfusions, postoperative thrombocyte and hemoglobin levels were recorded.

Results: Operating time was median $115 \mathrm{~min}$ (75-230) in the stapler group and $120 \mathrm{~min}$ (60-210) in the clip group, and there was no significant difference between the groups $(p=0.2593)$. There were no significant difference between the groups in terms of the postoperative complications ( $p=0.59)$. Postoperative hospital stay was median $3.5(2-8)$ days in the stapler group and $3(2-6)$ days in the clip group with no significant difference $(p=0.0733)$.

Conclusion: Clip ligation and en-bloc stapling techniques have no superiority over each other. Our results also showed that both techniques are safe and feasible. We suggest opting for the method according to the surgeon's experience and hospital facilities.

Keywords: Laparoscopic splenectomy, clip ligation, en-bloc stapling

Cite this article as: Türkoğlu A, Oğuz A, Yaman G, Gül M, Ülger BV. Laparoscopic splenectomy: clip ligation or en-bloc stapling? Turk J Surg 2019; 35 (4): 273-277.

Corresponding Author Ahmet Türkoğlu

E-mail: ahmetturkoglu04@gmail.com

Received: 02.10 .2018

Accepted: 18.12.2018

Available Online Date: 16.12 .2019

๑ Copyright 2019 by Turkish Surgical Society Available online at www.turkjsurg.com

DOI: $10.5578 /$ turkjsurg.4276

\section{INTRODUCTION}

Splenectomy is indicated in a large number of benign and malignant conditions. In total, the most common indication for splenectomy is spleen injury, and open surgery is performed in most of them. On the other hand, the most common indication for elective splenectomy is hematologic diseases, the most common being immune thrombocytopenic purpura (ITP). Laparoscopic splenectomy (LS) is recommended as the gold standard surgical approach for elective splenectomy (1). In experienced hands, LS provides many benefits, including less intraoperative blood loss, shorter hospital stay and lower morbidity when compared to open splenectomy (2).

During $L S$, splenic vessels can be clipped after separating them one by one via careful dissection of the splenic hilum, or the splenic hilum can be managed by en-bloc stapling. There are also some surgeons who use energy devices alone to divide the splenic vessels. All methods have various advantages and disadvantages, some of which are compared in the literature. However, to the best of our knowledge, there is no study in the literature comparing the results of clip ligating and en-bloc stapling techniques. In stapler usage, there are some concerns about possible rare complications such as arteriovenous fistula formation, bleeding from the transection line and pancreas or vascular injuries because of improper positioning of the stapler. In addition, cost of the stapler devices is more than that of the clips. In clip usage, on the other hand, splenic vessels need to be dissected one by one and isolated, which may entail a risk of bleeding and requires experience $(3,4)$. Hence, this study was aimed to compare our results of clip ligation and en-bloc stapling of the splenic hilum. 


\section{MATERIAL and METHODS}

The records of 67 patients undergoing laparoscopic splenectomy between December 2012 and October 2017 were retrospectively reviewed. Patients were divided into two groups according to surgical method (stapler group, 26 patients with endoscopic stapler; clip group, polymer clips, 41 patients). Converted cases (one in the stapler group and two in the clip group) were excluded from the study. Patient age, sex, indications for $L S$, surgical technique, operation time, spleen dimensions, perioperative complications, postoperative hospital stay, blood transfusions, postoperative thrombocyte and hemoglobin levels were recorded. Spleen sizes were obtained from preoperative ultrasonography or computerized tomography recordings. Although we considered ultrasonography adequate for preoperative accessory spleen research in previous years, computerized tomography has been started to be used routinely for the last three years.

For preoperative preparation; methyl-prednisolone or intravenous immunoglobulin was given to the patients with ITP and erythrocyte suspension to the patients with hereditary spherocytosis if needed. ITP patients were taken to surgery after raising their platelet levels to the appropriate levels for surgery. For this purpose, thrombocyte suspension was applied to the patients preoperatively and/ or perioperatively, and those whose platelet levels could not be elevated preoperatively, were given steroid therapy. All the patients received an anti-pneumonia vaccine 10 days before the surgery.

The study was designed in accordance with the principles of the Helsinki Declaration.

\section{Surgical Technique}

Patients were placed in right semi-decubitus and approximately $15^{\circ}$ reverse Trendelenburg position in general anesthesia for laparoscopic splenectomy. In most of the cases, a $30^{\circ}$ optic and 4 trocars were used. After exploration of the abdominal cavity and removal of the accessory spleen, if present, the splenocolic, gastrosplenic, splenorenal and splenophrenic ligaments attached to the splenic tissue were divided with energy dissection. Splenectomy was completed after the splenic hilus was divided by endoscopic stapler (Ethicon Endo-Surgery, LLC, Puerto Rico, USA) or splenic vessels were isolated and clipped (Changzhou Lookmed
Medical Instrument Co., Jiangsu, China). The spleen was placed in a sterile plastic bag and removed from the $15 \mathrm{~mm}$ trocar site after fractionated by overclamp to enable piecemeal removal. A negative pressure drain was placed in the left subphrenic area, if necessary. The removed spleen was sent for histopathological examination. 10 and 15 trocar sites were closed with number 1 vicryl.

Response to splenectomy was evaluated within the first month after surgery. American Hematology Association 2011 criteria were used in evaluating the response to splenectomy in ITP patients (5). These criteria are; 1-Complete response; The platelet levels of at least $100.000 / \mathrm{mm}^{3}$ without splenectomy treatment, 2- Partial response; Platelet levels between $30.000 / \mathrm{mm}^{3}$ and $100.000 / \mathrm{mm}^{3}$, or at least twice the basal level, 3-Complete unresponsiveness; Platelet levels below $30.000 / \mathrm{mm}^{3}$ or 2-fold below basal level.

\section{Statistical Analysis}

The data collected were analyzed using SPSS Statistics for Windows version 20.0 (SPSS Inc). The Kolmogorov-Smirnov test was used to test the normality of the variables. For the comparison of continuous variables, Mann-Whitney $\mathrm{U}$ test was used. Categorical variables were compared using a Pearson Chi-square test or Fisher's exact test. A p value $<0.05$ was considered statistically significant.

\section{RESULTS}

Totally, twenty-one (31.3\%) of the patients were male and 46 $(68.7 \%)$ of them were female. Median age of the patients was 35 (14-62) years. Median age was 36.0 (16-62) in the stapler group and 31.0 (14-39) in the clip group, with no significant difference $(p=0.2547)$. Median size of the spleen was 13 (11-20) in the stapler group and 13 (10-23) in the clip group with no significant difference $(p=0.3084)$.

In the stapler group, indications for the operations were ITP in twenty-one patients, hereditary spherocytosis in two patients, and thalassemia, splenic cyst and splenic infarct one in each case (Table 1). In this group, accessory spleen was detected in five patients (19.2\%) and removed during operation.

In the clip group, indications for the operations were ITP in 33 cases, hereditary spherocytosis in two cases, splenic cysts in five cases and lymphoma in one case (Table 1). Thrombocytosis de-

Table 1. Indications for laparoscopic splenectomy

\begin{tabular}{|l|c|c|c|}
\hline & Stapler group & Clip group & p \\
\hline ITP & 21 & 33 & \\
\hline Hereditary spherocytosis & 2 & - & 0.3553 \\
\hline Thalassemia & 1 & 5 & 1 \\
\hline Splenic cyst & 1 & - & \\
\hline Lymphoma & - & & \\
\hline Splenic infarct & 1 & & \\
\hline ITP: Idiopathic thrombocytopenic purpura. & & & \\
\hline
\end{tabular}


veloped in one (3.8\%) case with no need for anticoagulant treatment. Accessory spleens were detected and removed in four patients (9.8\%) during operation in this group.

Operating time was median $115 \mathrm{~min}$ (75-230) in the stapler group and $120 \mathrm{~min}$ (60-210) in the clip group, and there was no significant difference between the groups $(p=0.2593)$.

There were three cases converted to open, one in the stapler group and two in the clip group. The case in the stapler group bled after firing the stapler and we converted to open and ligated the vessels. Two cases in the clip group were converted due to the spleen sizes of more than $25 \mathrm{~cm}$ and difficulty in exposure.

Totally, postoperative complications developed in five (7.4\%) cases. Atelectasis developed in one (3.8\%) case in the stapler group and in two (4.8\%) cases in the clip group. Wound dehiscence developed in one case in each group. There was no significant difference between the groups in terms of postoperative complications $(p=0.59)$. In the stapler group, thrombocytosis developed in two (7.6\%) cases but anticoagulant treatment was needed in only one due to over 1 million platelet level. Thrombocytosis developed in onw (3.8\%) case in the clip group with no need for anticoagulant treatment. Postoperative hospital stay was median 3.5 (2-8) days in the stapler group and $3(2-6)$ days in the clip group with no significant difference $(p=0.0733)$ (Table 2).

Hematologic treatment continued because of persistent refractory thrombocytopenia in two patients, and temporary thrombocytopenia in five patients with ITP. In a patient with persistent refractory thrombocytopenia, an accessory/ectopic spleen was detected within the pancreas in a spleen scintigraphy performed postoperatively, and the patient continued to take hematologic treatment.
There were two patients (one in each group) who underwent concurrent cholecystectomy, and one umbilical hernia repair in the clip group. No deaths were recorded in both groups.

\section{DISCUSSION}

Since the first LS performed in 1991, this technique has been used increasingly and become the gold standard for elective surgery for splenic disorders $(6,7)$. In this technique, several methods have been used for division and management of the splenic hilus; such as endoscopic vascular staplers, polymer clips and energy devices (8). Although several papers have recently been reported on safety and feasibility of energy devices for the division of splenic vessels in adults, we use energy devices only for cutting splenic attachments. In the division of hilar vessels, we routinely use polymer clips or vascular staplers.

Endoscopic stapler is a safe and effective alternative instrument, especially for the first cases of training surgeons due to its relatively easy feasibility. Complications are rare when performed properly. However, it requires proper positioning as close as possible to the splenic hilum after sufficient separation of the attachments of the spleen. Inserting the device blindly on the hilar structures or removing it without firing is dangerous and may cause tearing of the thin-wall veins. Moreover, there are some concerns about the usage of endoscopic stapler such as bleeding from the transection line, injury to the pancreatic tail due to improper positioning of the device that results in pancreatitis or pancreatic fistula, metallosis or migration of the staples, and its costliness (9-12). AVF of the splenic vessels is a quite rare complication of LS. Due to the very close approximation of the splenic artery and vein, en bloc ligation of the splenic hilum may rarely cause AVF via injury to the vessel walls from the ligating staples. However, there is no risk of AVF in individual clipping of

Table 2. Patients' characteristics and results of surgery

\begin{tabular}{|c|c|c|c|}
\hline & Stapler group & Clip group & $\mathbf{p}$ \\
\hline \multicolumn{4}{|l|}{ Sex distribution } \\
\hline Female & 19 & 27 & 0.5376 \\
\hline Male & 7 & 14 & \\
\hline Median age & $36.0(16-62)$ & $31.0(14-39)$ & 0.2547 \\
\hline Median length of the spleen (cm) & $13(11-20)$ & $13(10-23)$ & 0.3084 \\
\hline Median operating time (min) & $115(75-230)$ & $120(60-210)$ & 0.2593 \\
\hline Median postoperative hospital stay (days) & $3.5(2-8)$ & $3(2-6)$ & 0.0733 \\
\hline \multicolumn{4}{|l|}{ Postoperative complications } \\
\hline Atelectasis & $1(3.8 \%)$ & $2(4.8 \%)$ & 0.59 \\
\hline Wound dehiscence & $1(3.8 \%)$ & $1(2.4 \%)$ & \\
\hline \multicolumn{4}{|l|}{ Refractory thrombocytopenia } \\
\hline Persistent & $1(3.8 \%)$ & $1(2.4 \%)$ & 0.9445 \\
\hline Temporary & $2(7.6 \%)$ & $3(7.3 \%)$ & \\
\hline
\end{tabular}


the splenic vessels $(4,11)$. In our case series, we did not encounter AVF or pancreatic injury but we converted to open due to bleeding from the transection line of the stapler in one case.

Various types of surgical clips are also used in LS to ligate the splenic vessels. Dissection of the splenic hilum and isolation of the splenic vessels are needed to place the clips, thus it necessitates advanced laparoscopic skill. In our study, in 26 of the cases splenic hilus was managed by endoscopic stapler and in 41 of the cases by clips. There was no difference in terms of operating time, hospital stay, intra-operative and post-operative complications. Within our knowledge, there is no study in the literature comparing clip and stapler techniques. We suggest that surgeons can choose anyone of these two techniques according to their own experience. Shabahang et al. have reported on 40 cases of LS to compare clip ligation with ligature during LS (3) They have suggested that both clip and ligature can be used for the ligation of the splenic hilum, but the risk of bleeding may be higher in clip ligation because dissection of the splenic hilum is usually needed in this method. Splenic hilar dissection necessitates advanced laparoscopic experience and as experience increases, complications decrease. Since an average of 3 or 4 clips are used during LS, we think clip ligation is more cost effective than stapler usage. Despite many reports on safety and feasibility of energy devices in splenic hilar management, a lot of surgeons still prefer using clips or stapler because of various concerns about ligature usage alone (2-4,7-12). The major concern is about bleeding because of cutting the vessels halfway without dissecting the splenic hilum and separating splenic artery and vein. On the other hand, in cases of separating the splenic vessels, why not use one or two clips to be safer about bleeding? We think the debate about the methods will continue and more prospective randomized studies are needed.

Another point of challenge for splenectomy is splenomegaly Is spleen size important in choosing surgery technique? Excessive size of the spleen may necessitate conversion to an open approach. Various definitions of splenomegaly have been used based on length and weight. An accurate cut-off point for the length doesn't exist for indication of open surgery. Many authors define splenomegaly as the length of the spleen being more than $15 \mathrm{~cm}$. In our study, median size of the spleens were similar in both groups. There were 4 cases which sized more than $15 \mathrm{~cm}$ in the stapler group and 3 in the clip group. The largest spleen size was $23 \mathrm{~cm}$ in our laparoscopically completed 67 cases. In two of the cases converted, conversion was due to the spleen sizes of more than $25 \mathrm{~cm}$. We did not find an importance of the spleen size in choosing the surgery technique. Independently of the aforementioned surgical techniques, early ligation of the splenic artery is proposed as a useful alternative method in cases with splenomegaly to reduce blood loss $(13,14)$. We use this approach not only in laparoscopic cases, but also in open cases with excessive spleen sizes with minimal blood loss.

In conclusion, according to our results, clip ligation and en-bloc stapling of the splenic hilum techniques have no superiority over each other. Our results also show that both techniques are safe and feasible. We suggest opting for the method according to the surgeon's experience and hospital facilities.

Ethics Committee Approval: Approval from the ethics committee of Dicle University School of Medicine was obtained (239/19.09.2018).

Informed Consent: Not required in this study.

Peer-review: Externally peer-reviewed.

Author Contributions: Concept - A.T., A.O.; Design - A.T., A.O.; Supervision - A.T., A.O.; Data Collection and/or Processing - G.Y.; Literature Search - A.T.; Writing Manuscript - A.T., G.Y.; Critical Reviews - A.O., M.G., B.V.Ü.

Conflict of Interest: The authors have no conflicts of interest to declare.

Financial Disclosure: The authors have no conflicts of interest to declare.

\section{REFERENCES}

1. Schwartz S, Brunicardi F, Andersen D, Billiar T, Dunn D, Hunter J, et al. Schwartz's Principles of Surgery. $10^{\text {th }}$ ed. Chap 34: Spleen. New York: McGraw-Hill, 2014.

2. Tada K, Ohta M, Saga K, Takayama H, Hirashita T, Endo Y, et al. Longterm outcomes of laparoscopic versus open splenectomy for immune thrombocytopenia. Surg Today 2018;48(2):180-5. [CrossRef]

3. Shabahang H, Maddah G, Tavassoli A, Jangjoo A, Alvandipour M, Abdollahi A, et al. Laparoscopic splenectomy: ligasure or clip ligation? Surg Laparosc Endosc Percutan Tech 2012;22(2):136-8. [CrossRef]

4. Vargün R, Göllü G, Fitöz S, Yagmurlu A. En-bloc stapling of the splenic hilum in laparoscopic splenectomy. Minim Invasive Ther Allied Technol 2007;16(6):360-2. [CrossRef]

5. Neunert C, Lim W, Crowther M, Cohen A, Solberg L Jr, Crowther MA. The American Society of Hematology 2011 evidence-based practice guideline for immune thrombocytopenia. Blood 2011;117:4190-207. [CrossRef]

6. Delaitre B, Maignien B, Icard P. Laparoscopic splenectomy. Br J Surg 1992;79:1334. [CrossRef]

7. Radkowiak D, Zychowicz A, LasekA, Wysocki M, Major P, Pędziwiatr $M$, et al. 20 years' experience with laparoscopic splenectomy. Single cen-ter outcomes of a cohort study of 500 cases. Int J Surg 2018;52: 285-92. [CrossRef]

8. Ji B, Liu Y, Zhang P, Wang Y, Wang G. A two-step control of secondary splenic pedicles using ligasure during laparoscopic splenectomy. Int J Med Sci 2012;9(9):743-7. [CrossRef]

9. Gelmini R, Romano F, Quaranta N, Caprotti R, Tazzioli G, Colombo G, et al. Sutureless and stapleless laparoscopic splenectomy using radiofrequency: LigaSure device. Surg Endosc 2006;20(6):991-4. [CrossRef]

10. Targarona EM, Espert JJ, Bombuy E, Vidal O, Cerdán G, Artigas $V$, et al. Complications of laparoscopic splenectomy. Arch Surg 2000;135:1137-40. [CrossRef]

11. Vargün Maleux G, Vermylen J, Wilms G. Lumbar artery pseudoaneurysm and arteriovenous fistula as a complication of laparoscopic splenectomy: treatment by transcatheter embolization. Eur Radiol 2002;12(6):1401-4. [CrossRef] 
12. Machado NO, Al Kindy N, Chopra PJ. Laparoscopic splenectomy using LigaSure. JSLS. 2010;14(4):547-52. [CrossRef]

13. Bani Hani MN, Qasaimeh GR, Bani-Hani KE, Alwaqfi NR, Al Manasra AR, Matani YS, et al. Laparoscopic splenectomy: consensus and debatable points. S Afr J Surg 2010;48(3):81-4.
14. Smith L, Luna G, Merg AR, McNevin MS, Moore MR, Bax TW. Laparoscopic splenectomy for treatment of splenomegaly. Am J Surg 2004;187(5):618-20. [CrossRef]

\section{ORIJINAL ÇALIŞMA-ÖZET}

Turk J Surg 2019; 35 (4): 273-277

\section{Laparoskopik splenektomi: klip ligasyon mu, enblok stapler mi?}

Ahmet Türkoğlu, Abdullah Oğuz, Gizem Yaman, Mesut Gül, Burak Veli Ülger

Dicle Üniversitesi Tıp Fakültesi, Genel Cerrahi Anabilim Dalı, Diyarbakır, Türkiye

\section{ÖZET}

Giriş ve Amaç: Laparoskopik splenektomi esnasında splenik hilus yönetiminde çeşitli teknikler kullanılmaktadır. Bunların arasında en sık kullanılanlar; polimer klipler, enblok stapler ve ultrasonik araçlar. Bildiğimiz kadarıyla, literatürde klip ve stapler tekniklerinin sonuçlarını karşılaştıran çalışma yoktur. Bu çalışmanın amacı, splenik hilus yönetiminde klip ligasyon ve enblok stapler yöntemlerinin sonuçlarını karşılaştırmaktır.

Gereç ve Yöntem: Aralık 2012 ve Ekim 2017 arasında laparoskopik splenektomi geçiren 67 hastanın kayıtları incelendi. Hastalar cerrahi yönteme göre 2 gruba ayrıldı (stapler grubu 26 hasta ve klip grubu 41 hasta). Hasta yaşı, cinsiyet, tanı, cerrahi teknik, operasyon süresi, dalak boyutu, perioperatif komplikasyonlar, postoperatif hastanede kalış süresi, kan transfüzyonu, postoperatif trombosit ve hemoglobin düzeyleri kaydedildi.

Bulgular: Operasyon süresi stapler grubunda ortalama 115 dakika (75-230) ve klip grubunda 120 dakika (60-210) idi ve gruplar arasında anlamlı fark saptanmadı $(p=0,2593)$. Postoperatif komplikasyonlar ve hastanede kalış süreleri açıından gruplar arasında anlamlı fark saptanmadı $(p=$ $0,59)$.

Sonuç: Klip ligasyon ve enblok stapler tekniklerinin birbirlerine göre üstünlüğü yoktur. Bizim sonuçlarımız gösteriyor ki iki teknik de güvenli ve uygulanabilirdir. Biz, yöntem seçimini cerrahın tecrübesine ve hastane imkanlarına göre seçilmesini öneriyoruz.

Anahtar Kelimeler: Laparoskopik splenektomi, klip ligasyon, enblok stapler

Doi: $10.5578 /$ turkjsurg.4276 